\title{
Nicaea as political orthodoxy: Imperial Christianity versus episcopal polities
}

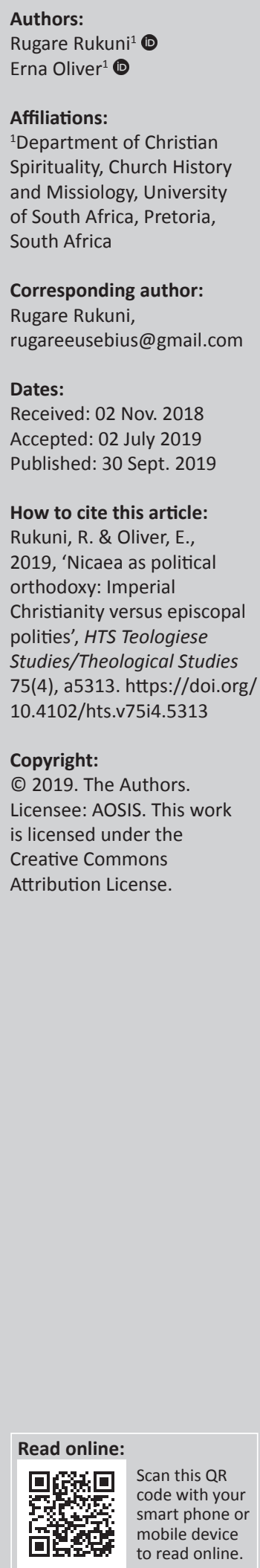

Fourth-century Christianity and the Council of Nicaea have continually been read as a Constantinian narrative. The dominancy of imperial Christianity has been a consequent feature of the established narrative regarding the events within early Christianity. There is a case for a revisionist enquiry regarding the influence of the emperor in the formation of orthodoxy. The role of bishops and its political characterisation had definitive implications upon Christianity as it would seem. Recent revisions on Constantine by Leithart and Barnes incited the enquiry. The enquiry was made possible through document analysis; this mainly took the form of a literature study. The orthodoxy that emerged at Nicaea in $325 \mathrm{CE}$ was reflective of the political-orthodoxy trajectory that Christianity took beyond the 4 th century. Between imperial intervention and clerical polities, one was a definitive dynamic to the then emergent Christianity. The influence of the emperor, which was an apparently definitive feature characterising the era, was compositely relevant as a catalyst in the formation of the Christianity that emerged during the 4th century. The implication that centuries before the Council of Nicaea Christianity had been characterised by significant phases of socio-cultural dynamics relegates the influence of the emperor. The emperor Constantine and his association with the Council of Nicaea characterised an era of imperial ecclesiastical politics in Christianity, and so did the Jewish-Christian Schism and a monarchical episcopate that shaped the orthodox matrix of the church. This research deduced that the function of imperial intervention should be analysed in conjunction with diverse factors characterising the Christianity emergent at Nicaea, particularly ecclesiastical polities.

Keywords: Church history; Imperial Christianity; Ecumenical orthodoxy; Ecclesiastical politics; Constantine, Self-definition and Nicaea.

\section{Introduction: Imperial Christianity in the shadow of Constantine}

Early Christianity's narrative at the turn of the 4th century is defined by the overwhelming imperial figure of Constantine as it would seem. The 325 CE Council of Nicaea, a milestone in the orthodox self-definition of Christianity, is a narrative between the lines of politics and orthodoxy. There has been resurgent debate concerning Constantine and his influence upon Christianity. Farreaching implications for ecclesiastical-political relations and orthodoxy hinge upon a review of this matter. The preceding fact builds a case for a revisionist approach to the relationship of the emperor Constantine with Christianity. It has been the purpose of the research to establish an alternative narrative to the emperor's intervention and the then emergent orthodoxy.

A diversified review of Constantinian scholarship enhanced a revisionist approach regarding this matter. Kee (2017) argued for a review of Constantine and Christianity based on primary evidence. The respective review, for example, would imply that recent conclusions regarding Constantine's conversion to Christianity are a modern oversimplification. Following this line of thought, the pagan background of the emperor would imply that we should distinguish between his devotedness to Christianity's God and not mistake this for assent to Christian conversion (Kee 2017:23). The emperor's affair with Christianity should not be underlined as evidence for his conversion; perceivably, a revision of Eusebius' Orations or his Life of Constantine can inform otherwise (Kee 2017:24). Kee's approach is one, amongst others, it would seem.

\section{Imperial influence versus episcopal polities}

For Brent, there is a continual swing of power between imperial influence and episcopal polities. Brent offers an alternative portrayal of a semi-pagan emperor who, despite his new Christian identity, still borrowed from pagan imperial tradition. Asserting himself as a religious benefactor, 
Constantine blended a religious posturing with the imperial authority (Brent 2009:286).

Problematically, it seems Constantine failed to attain to the Pontifex Maximus [high priest] role as had been the scenario with preceding significant emperors such as Augustus Caesar (27 BCE-14 CE_ (Lee 2006:160; Rowan 2018; Syme 2016). Whilst the emperors preceding Constantine were loyal to the traditional religions of Rome, Christianity during their reign can be argued to have been of marginal but expanding influence relative to later periods, as those defined by Constantine's ascendancy to sole emperorship (cf. Lenski 2006). Hence, the ability of Constantine to be the religious authority as per Roman custom could only be substantial in proportion to how the imperial establishment would relate to the new dynamic of Christian religion (Drake 2006:111; Edwards 2006:137)

Given the fact that Christians could not be part of the imperial cult, reactive imperial policy either had to be for their elimination or embrace (Lee 2006:160). On the contrary, Constantine's political prudence in toleration and identification with Christianity was nonetheless not equivalent to the religio-political significance derived from the imperial role of the Pontifex Maximus. Whilst the impossibility of a personality cult in Christianity stemmed from the religion's essential teachings, additionally the eminence of episcopal polity meant there was no room for another dominant figure of authority within the Christian hierarchy (cf. Brent 2009; Ignatius Eph 4.1-6.2; Schaff 1885a:101; Kyrtatas 2005:63). This rendered the political will of the emperor in ecclesiastical circles a function of episcopal connections, as bishops had become indispensable to imperial Christian policy. Implications from Brent's model trace to the fact that the inevitable but complementary role of emperor Constantine was composite to an enculturation and self-defining process within Christianity that preceded his political entrance. The respective process had forged an episcopal hierarchy (Ignatius Eph 4.1-6.2; Kyrtatas 2005:63; Schaff 1885a:101).

This clerical polity was the game-changing dynamic in Christianity with or without the emperor. The emergence of an ecumenical orthodoxy at the turn of the 4th century, as defined at Nicaea, can be attributed to Cyprian (cf. Brent 2009:286). The bishops retained an autonomous position according to this line of thinking. Citing Rapp (2005) and Norton (2007), Brent (2009) alludes:

It would be a mistake to see any radical, post-Constantinian, reconstruction of the roles of bishops and Synods so as to imagine that these had become creatures of Constantine's Empire resultant of his policies. (p. 286)

Some researchers do not interpret the eminence of the episcopal function as weakness on the part of Constantine. That is the bishops should not be understood to have been an element completely without the control of the emperor. Prominent Constantinian revisionist Leithart argued for an actively passive imperial policy. According to Leithart, the emperor's contact with Christian clerics was one of subtle influence; Constantine would not appear to meddle with Christian affairs, but correspondingly he would not be out of touch with organisational unity. This paradoxical approach is explained below.

\section{Passive imperial influence for promotion of unity}

Leithart portrayed a prudent emperor in a quest of selfredress. Emphasis is placed on how the emperor distinguished himself from the preceding tyrants (e.g. Decius, Diocletian, Maxentius and Licinius) as a liberator. The emperor's crusade was for concord, resorting only to violence to quell terrorism such as that of the Circumcellions (Leithart 2010:163; Augustine Clergy of Hippo Regius to Januarius (406/408) Eph 88.1, 6 Atkins \& Dorado 2001:144, 147). In harmony with his book entitled Defending Constantine, Leithart defends the emperor's endeavours for healing schisms fostering concord and creating a tolerant empire.

Regarding punitive legislation that was later codified in the Justinian and Theodocian Code, Leithart argued that the codification was a distortion of the imperial legislation as conceived by Constantine (Leithart 2010:198). The Justinian and Theodocian Codes when reviewed as codified versions of law imply an intention to echo a 'Constantinian tone'. However, these respective laws give a negative image of Constantine as a dictatorial emperor issuing decrees. This implies a departure from traditional Roman custom which implied a considerable regard for the senate in legislative and religious decisions (cf. Kelly 2006:195-198; Salzaman 2002:188)

Leithart argues, 'imperial legislation often functioned more as moral exhortation than as a code', despite being apparently influenced by Christianity, the conclusion that Constantine coined Christianised legislation is an overstatement (Leithart 2010:200). The emperor was rather creating an 'atmosphere of public disapproval' (Leithart 2010:200) against corruption and pagan sports (gladiator fights); this would be new policy guaranteeing a Rome en route to conversion as the Nova Roma with Christian paedeia [philosophic school] (Young 2006:485).

Leithart establishes a perspective that assumes a prudent Constantine that strove for concord in Christian circles. This conception of the emperor reshapes the Nicene narrative that was a definitive era in Christianity. A revision of the person of the emperor incited a probe regarding the prevalent feature in the formation of conciliar ecumenical dogma at Nicaea. That is between political and socio-ethnic dynamics what influenced the formulation of this orthodox modus in Christianity.

Historically, the tendency was to emphasise the influence of the neo-religio-political policy of the emperor. This possibly stemmed from the perception of the emperor as having made drastic changes in the traditions of pagan Rome. 


\section{Nicene orthodoxy as progressive imperial religious policy}

Alfoldi (1969) here serves as a representative of traditional scholarship. Alfoldi (1969:30) argued that Constantine embarked upon a trajectory of dynamic imperial religious policy. The two-dimensional phases emanate from his ascendancy after vanquishing the tyrant Maxentius at the Milvian Bridge. The period stretches for the duration of the uneasy peace with Licinius (312-320 CE), which was defined by an emperor seemingly tolerant to the traditional polytheism.

The second phase, 320-330 CE, is characterised by an emperor actively confronting paganism or polytheism whilst concurrently dabbling in ecclesiastics and syncing them with public life.

Consequently, Constantine made a name amongst pagans as the Novator turbatorque priscarum legume et morisantiquitus recepti [a wicked innovator and tamperer with the timehallowed laws and the sacred ethical traditions of our fathers] (Alfoldi 1969:31). This new religious pragmatism for which the emperor was criticised also entailed participation in the church's unanimous homogeneous agenda. The preceding imperial action of engaging ecclesiastics was an imperative because it implied tremendous implications on unity within the Roman Empire politically and socially in the least. It should be remembered that bishops as Christian leaders were significant figures within an extensive socioreligious network that was empire-wide (cf. Mitchell 2006:295; Trombley 2006:302).

Hence, Alfoldi portrays the missionary Constantine as 'the angel', 'servant of the Lord' and 'Christ's thirteenth apostle'. Conclusions from Alfodi arguably incite a trajectory towards comprehension of Constantine as an all-dominating emperor at Nicaea. Notably, the risk of such a conclusion would be its capacity to obscure realities of preceding formative catalyst that were definitive of Christian orthodoxy, such as philosophy, schismatic displacement and entrenchment (cf. Meisnner 2000).

There is, however, traditional scholarship divergent from this perception of the emperor.

\section{Ecumenical orthodoxy: Merger of ecclesiastical and imperial polities}

Schott (2008:124) developed an index of Constantinian scholarship, drawing from the example of Barnes (1981:245-261) and Drake (2000:286-287). He made distinctive categories between scholarships that either deciphered within ancient texts an anti-pagan or a religiously tolerant Constantine.

Barnes represents both traditional and modern Constantinian scholarship. The author of more than 20 titles on Constantine, Barnes implies his significance to the formulation of any perspective on Constantine's involvement at Nicaea. Barnes strongly acknowledged Drake's work on the Constantinianclerical polity matrix. This observation further entrenched the argument regarding Nicaea or ecumenical orthodoxy as an inceptive era for episcopal reign, consolidated through councils, political connections and a universal imperial network.

Barnes explicitly asserted that 'the Arian Controversy has close structural resemblance to modern party politics' (Barnes 2011:141). This conclusion that he attributes to contemporary discoveries implied that the apparent significance of the emperor Constantine was composite to an intricate formative era in Christianity. Therefore, reference to the imperial intervention, as an overarching theme with regard to Nicaea and Christian orthodoxy, becomes 'an oversimplification' in the words of Leithart (2010:254).

\section{Method}

The research presented in this article was mainly accomplished through document analysis. There was extensive use of literature throughout the research corpus.

\section{Nicaea as a political formation of orthodoxy}

The Arian controversy as the prelude to the first ecumenical council was an index to the geographical and political selfdefinition of Christianity. The preceding reality was arguably a consequence of the ecclesiastical-political establishment. The Nicene script has primarily been read in between the connotations of imperial Christianity or Constantine the Christian emperor. In perspective of the established views, it is the submission of this article that a revisionist review of Nicaea will substantiate grounds for an alternative narrative. In this particular case, one of the ecclesiastical politics intertwined with imperial involvement in the selfdefinition of Christianity.

\section{Arius the priest}

The key character from whom the name of the controversy was derived, Arius, was an influential Libyan priest who lived between 256 and 338 CE. His career was in the influential metropolis of Alexandria at Baucalis (Roldanus 2006:74). That the priest could be a crowd-puller in the city which had a history of idolising wisdom and philosophy seems to have been logical (cf. Socrates Hist 1.5; Schaff 1885f.:20).

Arius' doctrine was similar to Platonism, which is possibly another reason for his popularity amongst the disciples of philosophy. The other efficient element to the spread of Arius's doctrine was its adaptation into song that thereby implied its resonance with common populous (Philostorgius EH 2.2; Amidon 2007:15). As an index of the Hellenised Christianity that had emerged at the turn of the 4th century, the priest spoke in a middle-Platonic bubble. For Arius God was in his entirety transcendent, thereby emphasising the uniqueness of God from the rest of creation. Arius argued 
that God alone was 'unbegun', with the implications pertaining to his infinity and immutability (Arius Thalia; Roldanus 2006:75; Williams 2001:98-116).

\section{Ecclesiastical-political controversy}

Arius for his views together with two bishops from Cyrene, his home area, was then excommunicated by Alexander. In retaliation, Arius wrote letters of appeal to other bishops, in particular, Eusebius, the bishop of Nicomedia, who also happened to have been a fellow alumnus of the Antiochian Lucian school (cf. Socrates Hist Ecclest 1.15; Schaff 1885f.:45). He also appealed to Eusebius, the bishop of Caesarea, who was reputable for having audience with the emperor.

The intervention of Eusebius of Nicomedia in Arius's favour conjured up an episcopal turf war. Alexander wrote to the eastern bishops, raising the attention concerning an invasion of his see. The letter addressed to the bishop of Byzantine insisted that sympathising with Arius was tantamount to 'splitting the seamless robe of Christ that even the soldiers had dared not divide' (Behr 2004:64). This was in reference to the said disunity fomented by this controversy.

A revisionist reading of Eusebius affirmatively portrays the Arian controversy as a conflict of schools - those of Lucian and Origen (Ferguson 2005:24). Because Eusebius (of Caesarea) was affiliated with the school of Origen in Caesarea, an inclination in his narrative to establish a biased viewpoint could have been a possibility. To support this theory, the partial exclusion of Methodius of Olympus in Eusebius' (of Caesarea) documents can be attributed to the former's (Methodius) 'animosity' towards Origen. Details regarding Methodius, who was excluded from Eusebius, can be derived from Epiphanius of Salamis (Pan Haer 62.1464.19; Ferguson 2005:24; Williams 2009:130-134; cf. Carriker 2003). The scenario affirms the existence of an ecclesiasticalpolitical caste. The preceding assertion is substantiated by how the two influential Euseb(i) were on either sides of the controversy; whilst Eusebius of Caesarea was anti-Arian based on his Origenic background, Eusebius of Nicomedia was pro-Arian as fellow Lucian alumni with Arius (Philostorgius EH 2.14; Amidon 2007:30; Fergusson 2005:68-70).

Deductively, the Eusebian account illustrates a clash of ideologies, which prevailed throughout the era preceding Constantine's romance with Christianity, and resulted in the consolidation of episcopal powers by some elements. This is correspondent to the development of the history of Christianity as a narrative of self-definition. Therefore, the emerging ecclesiastical polity in the person of the bishops was a resurgent factor in the controversy, despite the imperial-political side of the Arian controversy. The schism establishes how there were political and ideological differences amongst the clergymen, and this would dictate the involvement of the emperor.

\section{Politics: Imperial influence and ecumenical orthodoxy The Neo-imperial religious policy}

The emperor's new religious policy was definitive of the Christian era which would then emerge. Christianity had seen persecution at the hands of Constantine's predecessors (Roldanus 2006), such as Galerius and Maximin (Cameron 2012:540). Constantine was the usher of a new empire; his iconic victory against Maxentius at the Melvian Bridge of the River Tiber paralleled Julius Caesar's Rubicon (cf. Rowan 2018). After crossing these rivers (Tiber and Rubicon) as consequent of gaining ground against their opponents, both emperors went to acquire persona defined by magnanimity and majesty.

Julius Caesar who became sole emperor 'Augustus', undoing the triumvirate after his victory at the Rubicon, was matched by Constantine, who after his victory embarked on a trajectory that consummated in his sole emperorship, thereby undoing Diocletian's invention of the tetrarchy (DMP 44.5-6; Schaff 1885d:486-4487; Lenski 2006:71). After Constantine assumed a religious triumph, he regarded the Melvian Bridge as the inception of ecclesiological politics or imperial intervention in the church, whichever way the imperial patronage became an element in the definition of Christianity.

\section{Emperor and Nicaea}

The emperor had lessons in dealing with Christianity, from an African leadership squabble in Carthage (cf. Edwards 2006; Roldanus 2006). The aforementioned religious diplomatic experience from the (African) Donatist controversy was here put to use through the support of a council. The summons of the emperor to a council handling the Arian matter did not get the intended complete response of Christendom; however, it seemed an acceptable one in terms of geographical representation comprising 320 delegates against the intended 1800 clerics (Sozomen Hist Ecclest 1.17; Schaff 1885f.:359). The cordiality of the new imperial regime to Christianity was signified in personalised invites through Hosius of Cordova, the bishop of Spain (Behr 2004:65).

The travel and opulence associated with the convention were at the emperor's expense. Constantine went beyond the provisions and displayed a personality that implied a due respect and regard for the institution of the church. Notably, the emperor openly honoured the heroes of the persecution (VC 3.10; Schaff 1885e:789; cf. Leithart 2010). The euphoria that traces Eusebius' account is correspondent to how the actions of the emperor poised him as the liberator of the church and no longer the tyrant, but Moses and Christ's 13th apostle (VC 2.28.2; Schaff 1885e:766).

The emperor's actions paint a narrative of expediency. It seems what was critical with Constantine was concord. His obvious presence was not a hindrance to the philosophical 
dilemma (cf. Leithart 2010; Roldanus 2006:80), but rather his interposition was to aggregate the discussion into a pursuit of unity. The emperor did not extinguish the religious debate by his attendance; he emphasised, however, the need for peace within Christianity. Constantine as a shrewd politician strove to note and buttress the majority of orthodoxy and then forced the rest to fall in with these (VC 3.4; Schaff 1885e:786). This implied that favour with the emperor and capable scholarship could win the day. However, this also created a future problem as visible in Constantine's aftermath support of Arianism. Notably, the emperor was one carried along with a debate that he was not fully comprehensive of. Arguably, Nicaea would be a consummative phase in Christianity's political self-definition. This would be a significant event in Christianity in the 4th century politically as it re-imaged the bishops and emphasised their new relation with the imperial establishment. When considered in the perspective of the preceding era of 100-300 CE where Christianity had undergone alienation with Judaism and a corresponding embrace of Hellenic features, this rewrites the narrative of Christianity (Boyarin 2010; Nickelsburg 2003; cf. Rukuni 2018).

\section{Anti-Judaism in the Neo-religious policy}

Nicaea seems to have been a convergence of three phases and factors that had been definitive of Christianity in the preceding centuries, that is, the Jewish-Christian Schism, Hellenism and politics. Nickelsburg (2003) established that despite Marcion's radicality his ideas of anti-Judaism shaped the anti-Judaic trajectory in the Christian church.

Nicene council issued cannons that outlawed the celebration of Easter in conjunction with Jewish festivity. Because Easter customarily coincided with the Jewish Passover on 14 Nisan, the Christian festival was therefore associated with Jewishness (cf. Eusebius Hist Eccl 5.23.2-3; Schaff 1885e:275). In addition, there would be a standardisation of the liturgical exercises in Africa, Egypt, Libya, Greece, Asia and Pontica (VC 3.18.3; Schaff 1885e:793). The western church's 40 days of lent during Easter was now a universal practice (Barnes 2011:125). The anti-Judaism inferred from the prohibition of keeping Easter simultaneously with the Passover indicates how Christianity in self-definition that was now bracketed in imperial connotations was continually severing ties from its Judaic origins.

In Constantine's words, the Jews were guilty of 'deicide' (murder of God) (cf. VC 3.18.2-4; 19.1; Schaff 1885e:793, 794): 'It's unworthy to accomplish that most holy festival following the custom of the Jews, who have sullied their hands with a lawless crime are predictably polluted and spiritually blind' (Barnes 2011:124). The notion of ancestral guilt, prevalent in Matthew 27:23, became a common theme of theological ideology, as seen in Tertullian's works.

In On Prayer 14 (Schaff 1885b:276-277), Tertullian mocked the Jews as perpetually unclean, even if they wash daily - the stain of prophetic martyrs' blood and that of Jesus was an irremovable stain upon them (Barnes 2011:125). Nicaea being the backdrop of this form of ideology gave ground for conclusions regarding what influence was more dominant in the formation of Christian orthodoxy.

Arguably, the council can be understood as a consolidation of events in Christianity that had transpired in the preceding centuries. This observation can be viewed in a tripartite phase of catalysts argued to have defined Christianity. Firstly, the Jewish-Christian Schism, although debateable in its impact and reality, was a significant event in the first 200 years of Christianity (cf. Boyarin 2010; Nickelsburg 2003; Rukuni \& Oliver 2019). Secondly, the Hellenic influence that defined Christianity's apologetics and theology in the late 1st century $\mathrm{CE}$ to the 3rd century CE was an apparent characteristic (cf. Drodge 2006; Rukuni 2018). Finally, the reality of a monarchical episcopate that now was in sync with the emperor defined the 3rd-4th century CE (cf. Drake 2006; Edwards 2006; Kyrtatas 2005:63; Rukuni 2018). In addition, there was entrenchment of respective theological ideology as a result of the emergent episcopal hierarchy that was characterised by ecclesiastical politics. This convoluted formula thereby conceived the post-Nicene era and correspondingly its orthodoxy.

\section{Neo-Christian policy}

Legislation for the promotion of Christianity would range from restrictions on Jews regarding their anti-Christian campaigns to more active laws for the building of churches rather than pagan temples (Eusebius Hist Eccl 10.6; Schaff 1885e:613-614). Certain ancient rites were banned, whilst there was promotion of open worship for Christians.

Overall, the reign of Constantine became the victorious age of Christianity. Eusebius (Hist Eccl 10.6; Schaff 1885e:613-614) compared the great deliverance of the Israelites from Egypt by Moses to the actions of the emperor. Eusebius seems to have been enthralled by the actions of the emperor, yet one has only to reconsider the persecution of earlier centuries or rather preceding emperors to understand why Christians would seem this amused. It was not all of Rome where the emperor would pull down pagan temples or remove nonChristians from office; it has to be noted that much of the Roman senate remained pagan, and it seems Constantine did not undermine them (Kreider 2013:49). Unlike Julius Caesar, despite his new sweeping rule Constantine's respect for the Senatorial aristocracy implied a regard for a pagan constituency in Rome (Ricketts 2018). The preceding observation confirms how politics was relatively prominent over religion in the emperor's power plays. According to Salzaman, interdependence between the emperor and the Roman senate implied this imperial regard for pagan aristocrats, and Constantine would not impose aristocratic conversion but rather he would make it politically attractive by attaching it with official elevation amongst other things (Salzaman 2002:188). 


\section{The East and a new Christian empire}

Christianity was now part of the new imperial matrix. Mutually it now defined the emperor's actions as much as his moves also influenced its political trajectory. When the emperor established a new Eastern Rome, it would be identified as Christian. The defeat of Licinius, his eastern counterpart who had gone rogue persecuting Christians and breaching truces (cf. Van Dam 2011) in 324 CE, forms the backdrop of the move East (Hist 1.4; Schaff 1885f.:19, 20). To have a city located at the intersection of the Asian and European coasts had economic and military advantages (Roldanus 2006:72).

Barnes proposes an alternative plot to the background narrative of Constantine's eastward move (Barnes 1981:210). After illustriously conquering Licinius - Christianity's new persecutor in the Eusebian accounts - Constantine had retrieved the mostly Christian east as per their population. He would then envision One Empire, One God, One Emperor (cf. Leithart 2010:248). A mostly unified empire-wide religion could achieve this objective.

This would be reason enough to build churches and promote Christianity in a non-compulsive manner for pagans (cf. Roldanus 2006:71). In his era, Constantine became a legend, Christ's thirteenth apostle. As 'the apostle of the new age and of equal success' (Roldanus 2006:71), Constantine was fulfilling his sense of divine duty.

The move to the east was premised on the inception of a New Empire - the New Rome agenda (Barnes 2011:108-109). Constantine, who would see the blessed faith increasing under his protective hand (VC 2.28.2; Schaff 1885e:766), established a Christian city and erased the pagan memories as he razed down Byzantium only to rebuild it (Barnes 2011:111).

There prevails a religious aura in the records pertaining to the founding of the city. Constantine was said to have been divinely inspired in the manner in which he determined the confines of the new city. The act was consummated by marching whilst holding his spear supposedly in obedience to divine biddings (Philostorgius Hist Eccles 2.9; 9; Barnes 2011:111; Pearse 2002:30). Confiscations from pagan temples would fund the extensive infrastructural policy of this emerging Christian metropolis (VC 3.58; 2-3; Schaff 1885e:811). This had obvious hostile implications upon the formerly persecuted Christian clergy and their pagan counterparts.

\section{The emperor against Paganism}

Upon the inception of the joint rule of Licinius and Constantine, an edict of tolerance had been issued. The edict was a sign of goodwill to all religions and people of Rome, both east and west. The persecution of bishops in the East by Licinius could be taken as an excuse by Constantine to have an offensive upon paganism. Arguably, if there was a pagan emperor in the eastern part of the empire persecuting Christianity, this meant pagan elements in Constantine's part of the empire would by default find common cause with the eastern side of the empire. This could prove politically fatal in the perspective of pagan aristocrats who could then plot against the emperor as was the case with Julius Caesar (Heather 1998:185-6; Ricketts 2018; cf. Potter 2013).

Shrines and temples were torn down correspondingly with the seizure of all forms of priced material inside and on the temples. This continued irrespective of the edict of toleration. Therefore, Constantinople paralleled the Milvian Bridge and the corresponding march through Rome - both were signs of Liberator Urbis [liberator of the City] theme. Constantinople signified a Liberator Ecclesiae [liberator of the church] theme. From another perspective, Constantine became a Christian tyrant, as reflected in his military policy to achieve the sole emperorship.

Whilst there were hostile policies for pagan infrastructure, the benefactions towards Christianity were to be seen as positive inducement for pagan conversion (Sozomen Hist Ecclest 1.5; Schaff 1885f.:344-345). There remained many shrines and pagan temples untouched (cf. Barnes 2011:111). The preceding actions are clarified when the emperor's primary policy is deduced as the political promotion of a new universal faith rather than the eradication of pagan traditions. Sozomen perceived the emperor would deconstruct the pagan complex by demystifying the sacred places and rites (Hist Ecclest 2.5; Schaff 1885f.:371-372). In the minds of the superstitious pagans once the holy places were desecrated and the ceremonies belittled, one could at least question the reality of their religion and even opt for the promoted Christian faith.

\section{An actively Christian emperor}

The sole emperorship of Constantine and the expansion towards east implied the imperial interest in eastern Christianity. The emperor's encounters with the Donatist schism had relatively served as a policy template (cf. Roldanus 2006). The emperor's religious policy script would be a composite narrative of actions for unity and concord. Through Hosius of Cordoba, a bishop from Spain, the emperor would be filled in regarding the theological and philosophical intricacy of the Nicene debate, which had, at the onset, been somewhat a trivial conflict over semantics for him (Hist 1.6; Schaff 1885f.:20-21; Vermes 2012:229). The implication of the emperor being informed regarding the technicalities of the debate taking place was his consequential active involvement in developing creeds that would shape Christendom.

The affirmation of Church creed or rather unanimous ecclesiastical agreements by imperial action was something preceding Constantine's golden age. Eusebius (in Hist Eccl 7.27-30; Schaff 1885e:501-508) records the intervention of pagan emperor Aurelian (270-275). This was in an episcopal 
turf war between Dionysius of Rome and Paul of Samosata, with the issue being primarily concerning Paul's Christology (Young 2012:467). A series of councils consummated in AD 268, where consensus saw Paul's condemnation as a heretic.

Despite his excommunication, Paul obstinately refused to cede a church building to his replacement. Pagan Dionysius, who was tolerant to Christians, responded to the church's appeal regarding this matter (Eusebius Hist Eccl 7.27-30; Schaff 1885e:501-508). The emperor reinforced the resolution of the council. These precedingly mentioned scenarios make the intervention of Constantine in ecclesiastical matters a consummative phase of a preconceived religio-political trajectory. The imperial involvement becomes a completing element in the orthodox self-definition of Christianity. PostConstantine imperial reinforcement of councils and canon law would universalise episcopal or ecclesiastical politics across Christendom.

\section{Imperial dis-taste for extreme views}

Nicaea as a venue for the council to reclaim the universal unity of Christendom implies an underlying political tone. Ancyra in the region of Galatia seemed geographically convenient because of its centrality for eastern and western Christendom for convening the council; however, possibly as an aversion of the intricacies in ecclesiastical polity, the emperor did not choose it as a venue. Marcellus', the bishop of Ancyra, influence would likely tilt the council. Nicaea, on the contrary, was in proximity with Nicomedia, the significance of this location was that it was within considerable radius of the prospectively new Christian capital Constantinople. In addition, the emperor's presence was guaranteed, thereby implying his active participation and observation (cf. Behr 2004:67).

The choice of Nicaea could also have been for ease and convenience, given the city's accessibility to western bishops and its favourable climate. Reiteratively, Drake (2006:125) argues that the avoidance of Ancyra was an active evasion of Marcellus, the bishop whose hard stance against Arianism would somewhat condition the council where he would be the presiding bishop. The incident with Miltiades in Rome in AD 313 had showed this possibility. Deductively, the emperor would set the ground for a more consultative approach, which would be more collective and inclusive. This could all have been window dressing so as to achieve a unified Christianity. The emphasis of the emperor would not be as that of the episcopate, that is, with regard to orthodoxy but rather unity.

Opposition to the creeds would ultimately be unwelcome threats to imperial or universal peace through the church. Deposition followed obstinacy, such as the case of two Libyan episcopates: Secundus of Ptolemais and Theonas of Marmarica. Correspondingly, Arius's acceptance of the creed was blended with subtle dissent that ultimately resulted in his imposed exile to Illyria (Behr 2004:68). The supervision of the magister officiorum [official], a government official in the signing of the creed, was indicative of how the religiopolitical controversy had become compositely a matter of both state and ecclesiastical affairs (Barnes 2011:122; cf. Philostorgius Hist Eccles 1.9a; Amidon 2007:12-13). Nicaea's centrality within the Christian narrative is its position as a convergence of the self-defining process in Christianity.

\section{Political-clerical connection}

Leithart (2010:177) hints for a revisionist approach as incited by the following enquiry: 'Did the church of the fourth century allow itself to be absorbed into the machinery of power? Did bishops ... lose their critical prophetic edge?' These respective questions find relevance in the background of Constantine's successors such as Constantius II, the 'bishop of bishops'.

In Eusebius' Life of Constantine, Constantine exclaimed, 'I too am a bishop, anointed by God' (VC 4.24; Schaff 1885e:826). Constantine, in the legislation he made, affirmed the role of the bishops in ecclesiastical issues, additionally extending their authority into secular matters. The composition of the bishopric later derived mainly from nobility and castes from the higher classes, as a function of the imperial enticements to clerical office than to municipal governance. Consequently, this new era implied that the episcopal network was modelled after imperial administration (Van Dam 2012:344).

The prominence, however, of Clerical polity as a definitive function in the formation of orthodoxy in Christianity argues for a different narrative even concerning Eusebius 'the great publicist of the first Christian emperor ... political theologian ... and ceasaropapist' (cf. Ferguson 2005:22-24; Hollerich 1990:309).

There is a case for a non-contact theory between the emperor and Eusebius. Arguably, there are assertions that Eusebius was not a courtier; therefore, there was little familiarity between him and the emperor (Barnes 1981:266; Leithart 2010:179). Notion concerning Eusebius is usually built from his biography and eulogy of Constantine; this is despite the fact that he also has apologetics and biblical works.

\section{Constantine and the bishop}

Using Eusebius as a figurehead for the clergy in Constantine's era, a review of his position regarding the relationship of the emperor and ecclesiastical polity enhances an understanding of 4th-century clerical-political ideology. Post-Nicaea, the Bishop Eusebius titled the church theosebes politeuma [godly polity], a constituency of the episcopate and not the emperor.

Eusebius' ideology was illustrated in his homily on Isaiah 11:6, where he interpreted the vision of a young boy leading wild animals to mean that the boy represented the clergy, whilst the animals were the imperial officials (Leithart 2010:179). Deductively, we can conclude that for Eusebius the emperor was a quasi-bishop and not the episcopus episcoporum [bishop of bishops], as claimed by Constantius II 
(Leithart 2010:180). The title 'bishop of bishops' would imply the emperor having explicit ecclesiastical authority and jurisdiction over the episcopate, such contact was evident in Constantine's successors, such as Constantius' attempt to realign the Egyptian and Aksumite clergy in perspective of his Arian views (Athanasius. Apol. 29, 31; Schaff 1885g:495, 497-498). Regarding the significance of episcopal politics in shaping Christianity rather than the emperor, inference can be made based upon the above-mentioned facts.

The background of the intransigent nature of African Christianity, with particular reference to the Donatist controversy, implies a logical inference to correspondence between theological divergence and political resistance in early Christianity. Perceivably, there is a traceable trend in early Christianity where political autonomy was a reason for non-conformity to a universalised orthodoxy. Cases other than the Carthage narrative include the non-Chalcedonian stance by Aksum and the Nicene versus non-Nicene ecclesiastical caste in Vandal Africa (Whelan 2018; Fulgentius V. Fulg. 6-7, 21, Eno 1997:16-21, 40-43; cf. Bowersock 2013). Amongst certain scholarship, the preceding was the norm (Leithart 2010:181). The preceding conclusion regarding political independence and theological divergence would principally guide our narrative of the early church; however, there were inconsistencies. The anti-Arian Athanasius posed resistance to the emperor at the conclusive stage of his career; this was despite his Alexandrian locale that implied he was securely within the emperor's grasp. Alexandria was in an undisputed Roman province of the Orient; hence, to find theological divergence in this locale would be an inconsistence to the proposed theory of political and religious conformity.

Given the holes poked in the image of an emperor worshiping Eusebius or clergy as per the view that postured him as the agent of imperial religio-political propaganda (cf. Fergusson 2005), there remains a question regarding the clerical-imperial political connection of the 4 th century. Scholarship has given an alternative meaning to the cosy relationship between the two polities in the era. Dagron (2003:129) and Leithart (2010:182-183), in similar manner to Roldanus (2006), argued that what seems to have been Eusebius' obsession with Constantine was a consequential euphoria then prevalent in 4th-century Christianity. The change in political fortunes was dynamic; the switch from imperially persecuted to imperially pampered overwhelmed the Christian world (Collier 2013:157). The preceding notion regarding the impact of changed fortunes for Christianity is further confirmed in Cavanaugh's review of Leithart's book (Cavanaugh 2013:85). Cavanaugh notes the essential nature of this argument as logical to the comprehension of 4th-century CE Christendom and its corresponding dynamics that would prevail into the following eras.

\section{The bishops and the emperor}

Constantine as benefactor had limits capturing the minds of his newly found equals. Beginning from him the role and figure of the emperor was to be demystified
(Leithart 2010:185). Athanasius later on registered his criticism of imperial influence through his protests. Influencing others, Athanasius in contact with Basil of Caesarea co-jointly instigated resentment of a governor with persecutory tendencies.

Basil boldly threatened action by publicising the deeds of the wicked governor, the fact that the governor was an imperial functionary would not in any way derail his crusade against him (Basil Epist 61; Leithart 2010:185; Schaff 1885h:479). The re-positioning of Constantine's grave at a distance from the 'apostles' was symbolic to the then emergent ideology postulated by Chrysostom. The imperial burial would be a statement of roles, that is his (Constantine) in the church that of a doorkeeper rather than 'an apostle' (Leithart 2010:185).

The formation of a monarchical episcopate and its corresponding claim to apostolic succession was a definitive element in Christian clerical polity. Coupled with the selfdefining emergence of orthodoxy, the emergent clerical or episcopal polity had substantial power. The church was the domain for the display of power by bishops rather than the emperor. Constantine unarguably made an impression as a saint, a result of his spiritual experiences (the visions and personal charisma), a distinguishing feature between him, his predecessors and successors (Leithart 2010:185). Despite Constantine's unique imperial persona and his promotion of Christianity, it seems the assertion of imperial influence would be of limited impact in conciliar politics (Roldanus 2006:40).

After Constantine, several emperors projected a non-contact approach to conciliar affairs (Dagron 2003:296-297). The emperor Theodosius sent Candidianus with directives rather than participate in the council of Ephesus. Constantine IV engaged the Pope regarding a resolution to the Monothelite controversy, harmonious to his hands-off policy with the episcopate. Correspondence between bishops Ossius of Corduba, Hilary of Poitiers and the emperor Constantius implies an assertion for an autonomous role of bishops independent of the emperor's influence. Hilary made candid and blunt admonitions by comparing Constantius to pagan persecutors: 'To thee, o Constantius, do I proclaim what I would have uttered before Nero ... Decius and Maximin' (Leithart 2010:187; Wickham 1997:104-107).

\section{Conclusion: Episcopal political power}

The sentiment for the independence and autonomy of the clergy in ecclesiastical affairs chronologically developed analogous to the self-definitive events in the history of Christianity. These mentioned events preceded the illustrious advent of the emperor Constantine upon the politicoreligious scene. Mutually, the development of the ideology that derived from an anti-Semitic and Hellenised apologetic was composite to the orthodoxy in which the emperor would 
take part in $325 \mathrm{CE}$. Another definitive composite factor in this self-defining process that had emerged and would intrinsically be part of the Christian orthodoxy was the ecclesiastical episcopal polities. This was a factor substantiated even by the events post-Nicaea. A more political bishopric was also the result of imperial intervention.

The principle of two forces is an example deduced from Gelasius' writings. Gelasius possibly provoked by imperial intrusion in ecclesiastical matters wrote illustriously to Anastasius. Gelasius (Letter of Gelasius to Anastasius Augustus PL 59:41-47; Robinson 1905:72-73) emphasised the subjection of the domain to two forces - the sacred authority (auctoritas) and the royal imperial power (potestas) (Drake 2006:413). This was not a figment of episcopal imagination. It would seem the episcopate would leverage public opinion as their trump card against the emperor (Ambrose Ep 40.11; Schaff 1885i:643).

The apparent existence of Christianity in the Empire made the clerics a force. Theodosius, for example, was threatened by the episcopate and clergy with uncontrollable negative sentiment, in what were generally volatile urban areas if he were to persecute the see of Callinicum (cf. Drake 2006:414). This fact coheres with the eminent primacy of the metropolitan sees, as the Empire had to make concessions with the church, which housed an autonomously influential polity.

The political implications of imperial Christianity upon the episcopacy had built upon a framework already in existence. Although a later phenomenon, the shift by aristocrats to the bishopric entailed language and ideals from imperial administration syncretised with Christian governance - this became consequent of the early 4 th century CE (cf. Kelly 2006).

Leithart cites Williams (2001:236-237), stating that the postNicene era proved that an imperially backed orthodoxy was not the solution for Christianity. It can be added that this orthodoxy could also not ensure momentum and flow of the self-defining process of Christianity. A deus ex machina (god from the machine; this means the emperor acted as a form of universalistic solution) on the imperial throne would not be sufficient to contain the philosophical self-defining turbulence that had brewed an emerging polity, assertive of their dogmatic authority (Leithart 2010:187). Therefore, a narrative on Nicene orthodoxy lacking emphasis on the intricacy of ecclesiastical politics would be in many ways incomplete.

Given the implications of the subject of imperial Christianity, the emperor Constantine and Christian orthodoxy upon politico-religious dialogue and conciliar orthodoxy, amongst other issues, a balanced narrative would be informative. Legislation regarding conscience or faith-related matters ought to derive checks and balances from this respective discussion. This is ultimately shaping dialogue on modern democracy and faith issues.

\section{Acknowledgements Competing interests}

The authors have declared that no competing interests exist.

\section{Authors' contributions}

Both R.R. and E.O. equally contributed to this work. R.R. is the main author. E.O. was responsible for the co-authorship, guidance and consolidation of process.

\section{Ethical consideration}

This article followed all ethical standards for carrying out research without direct contact with human or animal subjects.

\section{Funding information}

This research received no specific grant from any funding agency in the public, commercial or not-for-profit sectors.

\section{Data availability statement}

Data sharing is not applicable to this article as no new data were created or analysed in this study.

\section{Disclaimer}

The views and opinions expressed in this article are those of the authors and do not necessarily reflect the official policy or position of any affiliated agency of the authors.

\section{References}

Alfodi, A., 1969, The conversion of Constantine and Pagan Rome, Oxford University Press, Oxford.

Amidon, P.A., 2007, Philostorgius: Church history, Society of Biblical Literature, Atlanta, GA.

Atkins, E.M. \& Dorado, R.J. (eds.), 2001, Augustine political writings, Cambridge University Press, New York.

Barnes, T.D., 1981, Constantine and Eusebius, Harvard University Press, Cambridge.

Barnes, T.D., 2011, Constantine. Dynasty, religion and power in the Late Roman empire, Wiley-Blackwell, Chichester.

Behr, J., 2004, The Nicene faith: Formation of Christian theology, vol. 2. St Vladimir's Seminary Press, Crestwood, MO.

Brent, A., 2009, A political history of early Christianity, T \& T Clark, New York.

Bowersock, G.W., 2013, The throne of Adulis: Red Sea wars on the Eve of Islam, Oxford University Press, New York.

Boyarin, D., 2010, 'Judaism as a free church: Footnotes to John Howard Yoder's The Jewish-Christian Schism Revisited', in P. Dula \& C.K. Huebner (eds.), The New Yoder, pp. 1-17, Cascade Books, Eugene, OR.

Cameron, A., 2012, 'Constantine and the "peace of the Church"', in M.M. Mitchell \& F.M. Young (eds.), The Cambridge history of Christianity: Origins to Constantine, pp. 538-551, Cambridge University Press, New York.

Carriker, A.J., 2003, The Library of Eusebius of Caesarea, Brill, Boston, MA.

Cavanaugh, W.T., 2013, 'What Constantine has to teach us', in J.D. Roth (ed.), Constantine revisited: Leithart, Yoder, and the Constantinian debate, pp. 83-100, Pickwick Publications, Eugene, OR.

Collier, C.M., 2013, 'Leithart's defending Constantine: A review', in J.D. Roth (ed.), Constantine revisited: Leithart, Yoder, and the Constantinian debate, pp. 155-160, Pickwick Publications, Eugene, OR.

Dagron, G., 2003, Emperor and priest: The imperial office in Byzantium, transl. J. Birrell, Cambridge University Press, Cambridge.

Drake, H.A., 2000, Constantine and the bishops: The politics of intolerance, Johns Hopkins University Press, Baltimore, MD. 
Drake, H.A., 2006, 'The impact of Constantine on Christianity', in N. Lenski (ed.), The Cambridge companion to the age of Constantine, pp. 111-137, Cambridge University Press, New York.

Drodge, A.J., 2006, 'Self-definition vis-à-vis the Greco-Roman world', in M.M. Mitchell \& F.M. Young (eds.), The Cambridge history of Christianity: Origins to Constantine, pp. 230-245. Cambridge University Press, New York.

Edwards, M., 2006, 'The beginnings of Christianization', in N. Lenski (ed.), The Cambridge companion to the age of Constantine, pp. 137-158, Cambridge University Press, New York.

Eno, R.B. (trans.), 1997, Selected works (The fathers of the Church). Fulgentius, Saint Fulgentius Bishop of Ruspa, CUA Press, Washington, DC

Ferguson, T.C., 2005, 'The past is prologue: The revolution of Nicene historiography', in J. Den Boeft, J. Van Oort, W.L. Petersen, D.T. Runia, C. Scolten \& J.C.M. Van Winden (eds.), Supplements to Vigilae Christianae (formely Philosophia Patrum texts and studies of early Christian life and language, Brill, Leiden, Boston, MA.

Heather., P.J., 1998, 'Senators and senates', in The Cambridge ancient history, vol. 13 The Late Empire a.d. 337-425, 2nd edn., A. Cameron \& P. Garnsey (eds.), pp. 184-210, Cambridge University Press, Cambridge.

Kee, A., 2017, Constantine versus Christ: The triumph of ideology, Wipf \& Stock, Eugene, OR.

Kelly, C., 2006, 'Bureaucracy and government', in N. Lenski (ed.), The Cambridge companion to the age of Constantine, pp. 183-205, Cambridge University Press, New York.

Kreider, A., 2013, '“Converted” but not Baptised: Peter Leithart's Constantine project', in J.D. Roth (ed.), Constantine revisited: Leithart, Yoder, and the Constantinia debate, pp. 25-67, Pickwick Publications, Eugene, OR.

Kyrtatas, D.J., 2005, 'The significance of leadership and organisation in the spread of Christianity', in W.V. Harris (ed.), The spread of Christianity in the first four centuries: Essays in compilation, pp. 53-69, Brill, Leiden, Boston, MA.

Lee, A.D., 2006, 'Traditional religions', in N. Lenski (ed.), The Cambridge companion to the age of Constantine, pp. 159-180, Cambridge University Press, New York.

Leithart, P.J., 2010, Defending Constantine: The twilight of an empire and the dawn of Christendom, InterVarsity Press, Downers Grove, IL.

Lenski, N., 2006, 'The reign of Constantine', in N. Lenski (ed.). The Cambridge companion to the age of Constantine, pp. 59-90, Cambridge University Press, New York.

Mitchell, M.M., 2006, 'From Jerusalem to the ends of the earth', in M.M. Mitchell \& F.M. Young (eds.), The Cambridge history of Christianity: Origins to Constantine, pp. 295-301, Cambridge University Press, New York.

Nickelsburg, G.W.E., 2003, Ancient Judaism and Christian origins: Diversity, continuity and transformation, Fortress Press, Minneapolis, MN.

Norton, P., 2007, Episcopal elections 250-600: Hierarchy and popular will in Late Antiquity, Oxford University Press, Oxford.

Pearse, R., 2002. The ecclesiastical history of Philostorgius, viewed 08 February 2017 from http://www.Tertullian.Org/Fathers/Philostorgius.Htm.

Potter, D., 2013, Constantine the emperor, Oxford University Press, Oxford.

Rapp, C., 2005, Holy bishops in Late Antiquity, University of California Press, Berkeley, Los Angeles, London.

Ricketts, C., 2018, The Ides of March: The assassination of Julius Caesar explained, History Hit, viewed 25 June 2019, from https://www.historyhit.com/the-ides-of march-the-assassination-of-julius-caesar-explained/.

Robinson, J.H., 1905, Readings in European history, Ginn, Boston, MA.

Roldanus, J., 2006, The church in the age of Constantine: The theological challenges, Routledge, London, New York.

Rowan, C., 2018, From Caesar to Augustus (c. $49 B C-A D$ 14) using coins as sources, Cambridge University Press, New York.
Rukuni, R., 2018, 'The schism, Hellenism and politics: A review of the emergence of Ecumenical Orthodoxy AD 100-400', Master's dissertation, UNISA, Pretoria.

Rukuni, R. \& Oliver, E., 2019, 'A case for organic indigenous Christianity: African Ethiopia as derivate from Jewish Christianity', HTS Teologiese Studies/Theological Studies 75(1), a5270. https://doi.org/10.4102/hts.v75i1.5270

Salzaman, M.R., 2002, The making of a Christian aristocracy: Social and religious change in the western Roman Empire, Harvard University Press, Cambridge, MA.

Schaff, P. (ed.), 1885a, Ante-Nicene fathers, vol. 1: The Apostolic fathers with Justin Martyr and Irenaeus, Christian Classics Ethereal Library, Grand Rapids, MI.

Schaff, P. (ed.), 1885b, Ante-Nicene fathers, vol. 3: Latin Christianity: Its founder, Tertullian, Christian Classics Ethereal Library, Grand Rapids, MI.

Schaff, P. (ed.), 1885c, Ante-Nicene fathers, vol. 4: The fathers of the third century: Tertullian Part IV; Minucius Felix; Commodian; Origen, Christian Classics Ethereal Library, Grand Rapids, MI.

Schaff, P. (ed.), 1885d, Ante-Nicene fathers, vol. 7: The fathers of the third and fourth centuries, Christian Classics Ethereal Library, Grand Rapids, MI.

Schaff, P. (ed.), 1885e, Nicene and post-Nicene fathers, Series 2. vol. 1: Eusebius Pamphilius: Church history, life of Constantine, oration in praise of Constantine, Christian Classics Ethereal Library, Grand Rapids, MI.

Schaff, P. (ed.), 1885f, Nicene and post-Nicene fathers, Series 2. vol. 2: Socrates and Sozomenus ecclesiastical histories, Christian Classics Ethereal Library, Grand Rapids, MI.

Schaff, P. (ed.), 1885g, Nicene and post-Nicene fathers, Series 2. vol. 4: Athanasius: Select works and letters, Christian Classics Ethereal Library, Grand Rapids, MI.

Schaff, P. (ed.), 1885h, Nicene and post-Nicene fathers, Series 2. vol. 8: Basil: Letters and select works, Christian Classics Ethereal Library, Grand Rapids, MI.

Schaff, P. (ed.), 1885i, Nicene and post-Nicene fathers, Series 2. vol. 10: Ambrose: Selected works and letters, Christian Classics Ethereal Library, Grand Rapids, MI.

Schott, J.M., 2008, Christianity, empire, and the making of religion in Late Antiquity, University of Pennsylvania Press, Philadelphia, PA.

Syme, R., 2016, Caesar as Pontifex Maximus, Oxford Scholarship Online, https://doi org/10.1093/acprof:oso/9780198767060.003.0021

Trombley, F., 2006, 'Overview: The geographical spread of Christianity', in M.M. Mitchell \& F.M. (eds.), The Cambridge history of Christianity: Origins to Constantine, pp. 302-313, Cambridge University Press, New York.

Van Dam, R., 2011, Remembering Constantine at the Milvian Bridge, Cambridge University Press, New York.

Van Dam, R., 2012, 'Bishops and society', in A. Casiday \& F.W. Norris (eds.), The Cambridge history of Christianity: Constantine to c. 600, pp. 343-367, Cambridge University Press, New York.

Vermes, G., 2012, Christian beginnings: From Nazareth to Nicaea (AD 30-325), Penguin Group, London.

Whelan, R., 2018, Being Christian in Vandal Africa: The politics of Orthodoxy in the post-Imperial West, University of California Press, Oakland, CA.

Wickham, L.R., 1997, Hilary of poitiers, conflicts of conscience and law in the fourthcentury church, Liverpool University Press, Liverpool.

Williams, R., 2001, Arius: Heresy and tradition, rev. edn., Eerdmans, Grand Rapids, MI.

Williams, F., 2009, The Panarion of Epiphanius of Salamis, Book 1 (Sects 1-46), Brill, Leiden, Boston, MA.

Young, F.M., 2006, 'Monotheism and Christology', in M.M. Mitchell \& F.M. Young (eds.), The Cambridge history of Christianity: Origins to Constantine, pp. 452-469. Cambridge University Press, New York.

Young, F.M., 2012, 'Towards a Christian Paedeia', in M.M. Mitchell \& F.M. Young (eds.), The Cambridge history of Christianity: Origins to Constantine, pp. 485-503, Cambridge University Press, New York. 